\title{
Mempertimbangkan Logika Himpunan Kabur Masuk Dalam Kurikulum Matematika Sekolah
}

\author{
Ade Mirza \\ Pendidikan Matematika, FKIP Universitas Tanjungpura
}

\begin{abstract}
Abstrak
Logika klasik/tradisional atau logika tegas yang dipelajari selama ini di sekolah dan di awal masuk universitas, mempunyai nilai kebenaran yang dibagi secara dikotomi (benar/ya atau salah/tidak). Logika tegas ini ternyata belum mencakup fenomena sehari-hari dan alam pikiran manusia. Banyak hal yang menjadi tidak wajar bila dinilai dengan kebenaran yang besifat dikotomi tersebut. Karena, pada kenyataannya fenomena kehidupan cenderung lebih banyak yang bersifat kontinum, sehingga batas yang tegas menjadi suatu yang tidak jelas. Logika himpunan kabur merupakan konsep dasar untuk teori kabur (fuzzy theory) yang hadir untuk melengkapi/menyempurnakan logika klasik. Tulisan ini memberikan beberapa teori dasar sistem kabur dan gagasan mengenai perlunya logika himpunan kabur dimasukkan dalam kurikulum matematika sekolah.
\end{abstract}

Kata kunci: logika, himpunan, tegas, kabur

\section{Pendahuluan}

Himpunan dan Logika merupakan salah satu materi dasar yang sangat penting dalam mempelajari matematika lebih lanjut. Logika adalah kendaraan berpikir dalam matematika maupun dalam kehidupan sehari-hari. Matematika juga dipandang sebagai bahasa. Bahasa matematika diakui sebagai bahasa yang universal. Sebagai bahasa tentu mempunyai struktur. Strukur dari bahasa matematika adalah logika matematika. Pentingnya logika ini sebagai kendaraan atau sarana berpikir, memang sangat terasa ketika kita mempelajari materi matematika terutama dalam memahami konteks definisi, teorema, dan sejenisnya. Apalagi bila dihadapkan dengan masalah pembuktian. Melalui logika orang akan dapat berpikir secara kritis dan cermat. Bahkan, ada filosof yang mengatakan bahwa untuk menguasai dunia, maka kuasailah logika.

Selama ini, logika yang dipelajari di sekolah dan tingkat strata satu di perguruan tinggi di Indonesia umumnya adalah logika tradisional/klasik/tegas. Logika tradisional/klasik/tegas ini hanya membagi nilai secara dikotomi. Padahal, dalam kenyataan sehari-hari, banyak hal yang terjadi justru tidak secara dikotomi, misalnya siang dan malam, kita tidak bisa menentukan di mana batasnya. Kuat dan lemah, juga tidak jelas di mana batasnya, dan lainlain. Akibatnya, seringkali 
pembicaraan sehari-hari tidak terjamah oleh logika tegas tersebut.

Logika kabur (Fuzzy Logic) pertama kali dikenalkan oleh Lotfi A. Zadeh, seorang guru besar ilmu komputer pada universitas California di Berkeley pada tahun 1965. Pada dasarnya, logika kabur tersebut merupakan logika multi nilai, yang memberikan nilai antara untuk didefinisikan sebagai nilai di antara penilaian konvensional seperti benar/salah, ya/tidak, tinggi/rendah, dan sebagainya. Sistem logika kabur memberi kemungkinan bahwa sesuatu nilai bernilai benar dan salah secara bersamaan. Sebaliknya, nilai benar dan salah secara terpisah/tegas juga tercakup di dalamnya. Pendefinisian nilai antara tersebut memungkinkan dugaan seperti agak tinggi, ataupun sangat cepat dan lainnya yang serupa dapat diformulasikan atau dirumuskan secara matematis dan diproses dengan komputer, agar berlaku suatu cara berpikir yang lebih manusiawi dalam program komputer.

Sistem kabur merupakan suatu alternatif untuk menduga keanggotaan himpunan dan logika tradisional yang berasal dari filsafat Yunani masa lampau. Ketepatan matematika masa lampau, sebagian besar merupakan upaya Aristotles dan ahli filsafat sebelumnya dalam memikirkan suatu teori ringkas mengenai logika dan matematika di kemudian hari yang disebut "hukum-hukum berpikir" (lows of thought), salah satunya adalah "hukum mengeluarkan tengah" (Law of the Excluded Middle) yang menyatakan bahwa setiap pernyataan atau dalil (preposisi) yang manapun harus menjadi Benar atau Salah. Padahal, ketika hukum ini versi pertama kali diajukan oleh
Parminedes (sekitar 400 SM), di sana telah terjadi keberatan dan penolakan langsung yang sangat kuat antara lain oleh Heraclitus. Heraclitus menyatakan bahwa hal itu dapat serentak menjadi Benar dan Tidak benar. Plato adalah orang yang meletakkan fondasi mengenai apa yang disebut logika kabur saat ini dengan menandai bahwa ada daerah ke-tiga (di luar Benar dan Salah). Hal ini berlawanan dengan apa yang telah disampaikan. Selanjutnya, banyak ahli filsafat modern merasa tergerak seperti Hegel, Marx, dan Engels. Tetapi Lukasiewicz adalah orang pertama yang mengusulkan suatu alternatif sistematis untuk logika dua nilai dari Aristotles (Hellmann, http://fuzzy-logic-introduction.pdf) Logika kabur telah muncul
sebagai suatu alat yang menguntungkan untuk mengontrol dan mengatur sistem dan pembuatan barang industri yang kompleks, seperti peralatan elektronik, peralatan rumah tangga dan hiburan, sistem pakar dan aplikasi lainnya. Bahkan prinsip logika kabur telah merambah dalam dunia periklanan, sehingga promosi terhadap suatu produk menjadi sangat beragam. Untuk itu, pemahaman mengenai logika kabur ini perlu dikembangkan sejak dini, paling tidak di mulai dari tingkat sekolah menengah ataupun mahasiswa tingkat awal.

\section{Perbedaan Himpunan Kabur dan Himpunan Tegas}

Hal yang paling dasar dalam sistem kabur (fuzzy system) adalah suatu himpunan kabur (fuzzy set). Di dalam matematika klasik, kita telah 
terbiasa dengan apa yang disebut dengan himpunan klasik atau himpunan tegas (crisp sets). Himpunan tegas adalah himpunan dengan batasan yang jelas (Wang, 1997). Sebagai contoh Himpunan tegas $A$ adalah himpunan bilangan real yang lebih dari 6. Himpunan tersebut dapat dinyatakan sebagai $\mathrm{A}=$ $\{x / x>180\}$. Di sini tampak ada kejelasan. batas 6 tidak ambigu. Jika $x$ bilangan yang lebih dari 6 , jelas $x$ anggota $A$. Sebaliknya. tentu $x$ tidak termasuk dalam A.

Meskipun himpunan tegas/klasik cocok untuk bermacammacam aplikasi, dan telah terbukti menjadi alat penting bagi matematika dan pengetahuan komputer, namum himpunan klasik tidak menggambarkan konsep dan alam pikiran manusia yang cenderung menjadi abstrak dan tidak teliti. Sebagai illustrasi, kita dapat mengekspresikan secara matematika himpunan "manusia tinggi" sebagai himpunan orang yang memiliki tinggi badan lebih dari $180 \mathrm{~cm}$. Himpunan ini dapat ditunjukkan seperti himpunan A tadi. Jelas bahwa kita memisalkan $\mathrm{A}=$ "orang tinggi", dan $\mathrm{x}$ = "tinggi". Hal ini bukanlah cara yang alamiah, bahkan cara yang tidak sama untuk mewakili konsep biasa manusia tinggi. Pembagian dua alam/nilai pada himpunan klasik akan membagi atau mengelompokkan seseorang yang tingginya $180,1 \mathrm{~cm}$ sebagai orang yang tinggi, tetapi bukan orang tinggi bila tingginya $179,9 \mathrm{~cm}$. Perbedaan ini secara intuitif tidak masuk akal. Selisih atau kekurangan tersebut menyebabkan terjadinya peralihan yang drastis antara menjadi anggota dan tidak menjadi anggota dalam himpunan.
Bila nilai kebenaran secara tegas dinyatakan dengan $0=$ salah/tidak dan 1 = benar/ya maka dalam sistem logika kabur mencakup nilai dari 0 sampai dengan 1. Bila direpresentasikan nilai kebenaran logika tegas dan logika kabur dalam bentuk grafik, maka dapat dilihat pada gambar 1 dan gambar 2 berikut. (Diadaptasi dari Wang, 1997; dan Zimmermann, 1991).

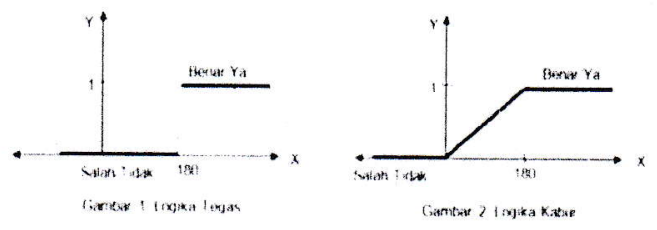

Bila sumbu datar $(X)$ adalah tinggi badan dan sumbu tegak (Y) adalah nilai kebenaran, maka pada gambar 1 , "orang tinggi" dengan ukuran lebih dari atau sama dengan $180 \mathrm{~cm}$ adalah benar $(Y=1)$, dan sebaliknya salah $(Y=0)$ bila ukuran tinggi kurang dari $180 \mathrm{~cm}$. Sedangkan pada gambar 2, ukuran tinggi antara 0 dan 180 mempunyai nilai benar dan salah secara bersamaan. Namun, seberapa besar kebenaran dan kesalahannya, tergantung pada karakteristik atau bobot keanggotaanya. Dengan demikian, berbeda dengan himpunan klasik/tegas, himpunan kabur adalah himpunan yang tidak memiliki batas yang jelas, sesuai namanya (himpunan kabur). Peralihan dari suatu anggota himpunan ke bukan anggota secara berjenjang yang dikarakterisasi atau dicirikan oleh fungsi keanggotaan (membership function).

Pada himpunan tegas (crisp), nilai keanggotaan suatu unsur $x$ dalam suatu himpunan A, yang sering ditulis 
dengan $\mu \mathrm{A}[\mathrm{x}], \quad$ memiliki 2 kemungkinan, yaitu:

1. satu (1), yang berarti bahwa suatu item menjadi anggota dalam suatu himpunan, atau

2. nol (0). yang berarti bahwa suatu item tidak menjadi anggota dalam suatu himpunan.

Contoh 1:

Jika diketahui:

$S=\{1,2,3,4,5,6\}$ adalah semesta pembicaraan.

$\mathrm{A}=\{1,2,3\}$

$\mathrm{B}=\{3,4,5\}$

Dapat dikatakan bahwa:

1. Nilai keanggotaan 2 pada himpunan $\mathrm{A}, \mu \mathrm{A}[2]=1$, karena $2 \in A$.

2. Nilai keanggotaan 3 pada himpunan $\mathrm{A}, \mu \mathrm{A}[3]=1$, karena $3 \in A$.

3. Nilai keanggotaan 4 pada himpunan $\mathrm{A}, \mu \mathrm{A}[4]=0$. karena $4 \notin \mathrm{A}$.

4. Nilai keanggotaan 2 pada himpunan $\mathrm{B}, \mu \mathrm{B}[2]=0$, karena $2 \notin B$.

5. Nilai keanggotaan 3 pada himpunan B. $\mu \mathrm{B}[3]=1$. karena $3 \in B$.

\section{Terminologi Himpunan Kabur dan Implementasinya}

\footnotetext{
Berbeda dengan himpunan klasik/tegas, himpunan kabur mengekspresikan derajat unsur yang termuat dalam suatu himpunan. Fungsi keanggotaan atau fungsi karakteristik himpunan kabur membolehkan mempunyai nilai antara 0 hingga 1 yang menyatakan derajat keanggotaan suatu unsur dalam himpunan yang diberikan.
}

Definisi 1: (Himpunan kabur)

Jika X adalah koleksi obyek-obyek yang dinyatakan secara umum (generic) oleh $\mathrm{x}$, maka himpunan kabur A di X didefinisikan sebagai himpunan pasangan terurut $A=\left\{\left(x, \mu_{A}(x)\right) \mid x \in X\right\}$. Di sini, $\mu_{A}(x)$ disebut fungsi keanggotaan (membership function) atau disingkat MF untuk himpunan kabur A. MF memetakan setiap unsur $\mathrm{x}$ ke nilai/derajat keangotaan antara 0 dan 1. (Jang. 1997).

Jelas bahwa definisi himpunan kabur merupakan perluasan dari himpunan klasik/tegas yang membolehkan fungsi karakteristik mempunyai nilai antara 0 dan 1. Jika MF terbatas pada salah satu nilai 0 atau 1 , maka $A$ direduksi ke himpunan klasik. Biasanya $X$ merujuk pada semesta pembicaraan (semesta) dan konsisten untuk obyek-obyek diskrit (terurut atau tak terurut) atau ruang kontinu. Untuk memahami himpunan kabur ini dapat dijelaskan melalui contoh berikut.

Contoh 2. Misalkan:

1. $\mathrm{A}=$ Himpunan banyaknya anak yang ideal dari suatu keluarga

2. $B=$ Usia sekitar 50 tahun

3. Misalkan $\mathrm{X}=$ \{Pontianak, Jakarta, Banjarmasin\} menyatakan himpunan kota-kota yang dipilih salah satu untuk di tinggali. Bila $\mathrm{C}=$ "kota yang diinginkan sebagai tempat tinggal" yang diseskripsikan sebagai $\mathrm{C}=\{($ Pontianak, 0,8), (Jakarta, 0,9), (Banjarmasin, $0,6)\}$

Jelas bahwa semesta pembicaraan (X) dari himpunan $\mathrm{C}$ tersebut adalah 
diskrit dan memuat obyek yang tak terurut. Dalam kasus ini derajat keanggotaanya sangat subyektif. Siapa saja dapat mengajukan nilai yang berbeda. Sedangkan semesta $\mathrm{A}$ adalah himpunan kảbur dengan semesta diskrit terurut. Deskripsi A dapat diberikan seperti berikut. Misalkan $X=\{0,1,2,3,4,5,6\}$ sebagai himpunan banyaknya anak dalam suatu keluarga. Maka himpunan kabur $\mathrm{A}=$ "banyaknya anak yang ideal dalam suatu keluarga" akan dideskripsikan sebagai berikut.

$$
\begin{aligned}
& A=\{(0,0.1),(1,0.3),(2,0.7), \\
& (3,1),(3,0.7),(5,0.3),(6,0.1)\}
\end{aligned}
$$

Selanjutnya, semesta untuk B adalah kontinu. Misalkan $\mathrm{X}=\mathrm{R}^{+}$menyatakan himpunan usia yang mungkin dalam kehidupan. Himpunan kabur $\mathrm{B}=$ "usia sekitar 50 tahun" dapat diekspresikan sebagai $\mathrm{B}=$ $\left\{\left(x, \mu_{B}(x)\right) \mid x \in X\right\}$. Di sini dipilih $\mu_{B}(x)=\frac{1}{1+\left(\frac{x-50}{10}\right)^{4}}$ (Jang, 1997).

Fungsi keanggotaan (MF) dari himpunan kabur A dapat ditunjukkan seperti gambar 3 dan himpunan $B$ ditunjukkan pada gambar 4 .
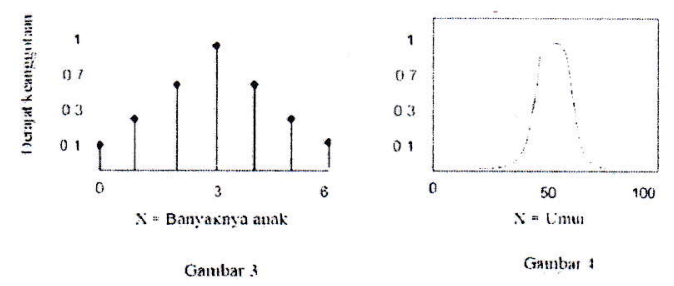

Berdasarkan uraian di atas, jelas bahwa himpunan kabur bergantung pada dua hal, yaitu mengidentifikasi semesta yang cocok dan menentukan fungsi keanggotaan yang sesuai. Penentuan fungsi keanggotaan sifatnya sangat subyektif, artinya untuk konsep yang sama fungsi keanggotaannya dapat bermacamacam dari individu yang berbeda. Misalnya. "banyak anak yang ideal pada suatu keluarga“ dapat dimaknai berbeda-beda oleh setiap individu. Subyektivitas tersebut berasal dari perbedaan individu dalam menangkap atau mengungkap konsep abstrak. Subyektivitas ini sangat kecil kaitannya dengan peluang (keacakan). Subyektivitas dan ketidakacakan merupakan perbedaan yang paling utama antara belajar himpunan kabur dan teori probabilitas - yang memperlakukan perlakuan obyektif dari fenomena acak. (Jang, 1997).

Notasi sederhana (*) untuk menyatakan himpunan kabur A adalah sebagai berikut.

$A= \begin{cases}\sum_{1} \mu_{A}\left(x_{i}\right) / x_{i} & \text {,jta X koletsi dart obyek distrit } \\ \int_{X} H_{A}\left(x_{i}\right) / x_{i} & \text { jikn Xruang kontinu (biasanya Real) }\end{cases}$

Tanda sigma dan integral pada notasi sederhana $\mathrm{A}$ di atas merupakan gabungan pasangan $\left(x, \mu_{A}(x)\right)$, sehingga tidak menunjukkan penjumlahan dan pengintegralan, demikian pula tanda "/" bukanlah menunjukkan pembagian.

\section{Ekspresi Alternatif}

Memperhatikan notasi sederhana $\left(^{*}\right)$ tadi, kita dapat menulis kembali suatu himpunan kabur dari contoh 2 sebagai berikut.

$$
\mathrm{A}=0.1 / 0+0.3 / 1+0.7 / 2+
$$

$$
1.0 / 3+0.7 / 4+0.3 / 5+0.1 / 6
$$

$$
\mathrm{B}=\int_{R^{+}} \frac{1}{1+\left(\frac{x-50}{10}\right)^{4}} / x
$$

$\mathrm{C}=0.8 /$ Pontianak + $0.9 /$ Jakarta $+0.6 /$ Banjarmasin Dalam praktek, bila semesta $X$ adalah ruang kontinu (garis bilangan real atau himpunan bagiannya), maka 
biasanya kita membagi $X$ ke dalam beberapa himpunan kabur yang MFnya meliputi $X$ kurang lebih dengan cara seragam.

Himpunan kabur biasanya mempunyai nama-nama sesuai dengan sifat-sifat yang tampak pada pemakaian bahasa sehari-hari. Kata "besar", "sedang", atau "kecil" misalnya, disebut nilai bahasa atau label-label bahasa. Karena itu, semesta dari X acapkali disebut variabel bahasa (variabel linguistik). Definisi formal variabel bahasa/linguistik dan terminologi lainnya yang terkait dapat diberikan sebagai berikut. (Jang, 1997; Wang. 1997; Zimmermann, 1991).

Definisi 2. (Variabel bahasa/linguistik dan terminologi lainnya yang terkait) Variabel bahasa/linguistik dicirikan oleh 5-tupel (quintuple) yaitu (x, T $(x)$, $X, G, M)$ dimana

- $x \quad$ : adalah variabel.

- $T(x)$ : himpunan istilah (term set) dari x - yaitu himpunan dari nilai linguistik $\mathrm{x}$, atau istilahistilah linguistk dari $\mathrm{x}$

- X : semesta pembicaraan

- G : aturan sintaktikyang membentuk istilah dalam $T(x)$

- M : aturan semantik yang mengasosiasikan dengan setiap nilai linguistik A dengan maknanya $\mathrm{M}(\mathrm{A})$. dimana $M(A)$ menyatakan himpunan kabur dalam X.

Untuk membantu memahami definisi 2 tersebut, berikut diberikan contoh mengenai variabel bahasa (variabel lingusitik) dan nilai bahasa (nilai linguistik).
Andaikan $X=$ "usia", maka kita dapat mendefinisikan himpunan kabur "muda", "parobaya", dan "tua" yang dikarakterisasikan oleh fungsi keanggotaan (MF) berupa : $\mu_{\text {muda }}(x), \quad \mu_{\text {parobaya }}(x) . \quad$ dan $\mu_{\text {tua }}(x)$. Jika usia diinterpretasikan sebagai variabel bahasa, maka bentuk himpunan $\mathrm{T}($ usia) dapat dinyatakan sebagai:

$\mathrm{T}($ usia $)=$ 'muda, tidak muda, sangat muda, tidak sangat muda. .... umur menengah/parobaya. umur tidak parobaya. ... tua, tidak tua, sangat tua, kira-kira tua, tidak sangat tua, . . . tidak sangat tua dan tidak sangat muda, ....?

Di sini setiap istilah dalam $\mathrm{T}$ (usia) mencirikan himpunan kabur dari suatu semesta pembicaraan $X=[0$, 100] seperti ditunjukkan pada gambar 5. Biasanya kita menggunakan kata "usia muda" untuk menyatakan tanda dari nilai bahasa "muda" untuk variabel bahasa "usia". Sebaliknya, bila usia diinterpretasikan sebagai variabel numerik, kita menggunakan ekspresi "usia $=20$ " dari pada numerik "20" untuk menyatakan variabel numerik usia. Aturan sintaktik menunjuk pada nilai bahasa dalam himpunan istilah $T$ (usia) yang dibangkitkan. Sedangkan aturan semantik mendefinisikan fungsi keanggotaan dari setiap nilai bahasa

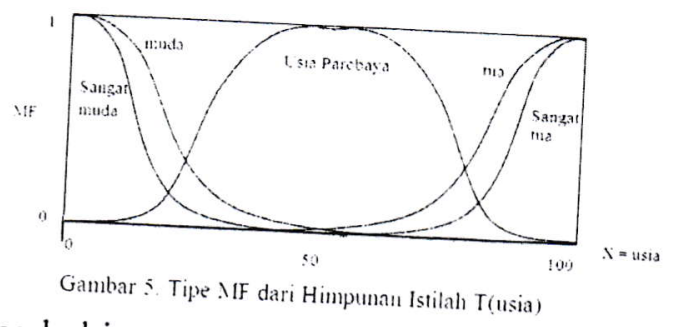

pada himpunan istilah tersebut. 
Pada contoh variabel bahasa tersebut, kita dapat melihat bahwa himpunan istilah itu terdiri dari beberapa istilah dasar (primary terms). yakni: muda. probaya, dan tua. Selanjutnya dimodifikasi dengan negasi ( $n o l$ lidak). dan atau penegas (hedges) seperti: sangat, kira-kira, ekstrim. dan lain-lain. Kemudian dihubungkan dengan kata hubung seperti: dan. atau, salah satu, tidak satupun. dan sebagainya. Akibatnya, kita memperlakukan kata hubung, penegas. dan negasi sebagai operator yang mengganti makna dari operasinya dalam satu ketentuan.

Beberapa hal dasar yang perlu diperhatikan juga dalam konteks sistem kabur, diberikan dalam definisi sebagai berikut.

Definisi 3. Support (Pendukung)

Support dari himpunan kabur B adalah himpunan dari semua titik $\mathrm{x}$ di $X$ sehingga fungsi keanggotaan $B$ positif $\left(\mu_{B}(x)>0\right)$. Support $(B)=$ $\left\{x \mid \mu_{B}(x)>0\right\}$

Definisi 4. Core (Inti)

Core dari himpunan kabur $\mathrm{B}$ adalah himpunan semua titik $\mathrm{x}$ di $\mathrm{X}$ sehingga $\mu_{B}(x)=1$. Core $(B)=\left\{x \mid \mu_{B}(x)=\right.$ $1\}$

Definisi 5. Normality (Normalitas)

Himpunan kabur B adalah normal jika core-nya tidak kosong. Dengan kata lain, kita dapat mencari $\mathrm{x}$ anggota $\mathrm{X}$ sehingga $\mu_{B}(x)=1$

Definisi 6. Crossover point (Titik silang)

Crossover point dari himpunan kabur $\mathrm{B}$ adalah titik $\mathrm{x}$ anggota $\mathrm{X}$ sedemikian hingga $\mu_{B}(x)=0.5$. Crossover point $(\mathrm{B})=\left\{x \mid \mu_{B}(x)=0.5\right\}$
Definisi 7. Fuzzy singleton (Titik tunggal)

Himpunan kabur yang support-nya adalah titik tunggal di $X$ dengan $\mu_{B}(x)=1$ disebut titik tunggal (fuzzy singleton)

Definisi $\quad 8 . \quad \alpha$-cut, dan $\alpha-$ cut kuat

$\alpha$-cut atau himpunan $\alpha$-level dari himpunan kabur $B$ adalah himpunan klasik yang didefinisikan oleh $\quad A_{\alpha}=\left\{x \mid \mu_{B}(x) \geq \alpha\right\}$. Sedangkan untuk $\alpha$-cut kuat dinyatakan sebagai $\quad A_{\alpha}^{\prime}=$ $\left\{x \mid \mu_{B}(x)>\alpha\right\}$.

Memperhatikan notasi definisi ini maka dapat diperoleh support dan Core dari suatu himpunan kabur $B$ sebagai berikut. Support $(\mathrm{B})=A_{0}^{\prime}$ dan Core $(\mathrm{B})=A_{1}^{\prime}$

Definisi 9. Convexity (Konveksitas) Himpunan kabur B adalah konveks jika dan hanya jika untuk sebarang $x_{1}, x_{2} \in X$ dan $\gamma \in[0,1], \mu_{B}\left(\gamma x_{1}+(1-\gamma) x_{2}\right) \geq$ $\min \left\{\mu_{B}\left(x_{1}\right), \mu_{B}\left(x_{2}\right)\right\}$

Definisi 10. Fuzzy number (Bilangan kabur)

Bilangan kabur $\mathrm{A}$ adalah himpunan kabur di dalam garis real (R) yang memenuhi kondisi kenormalan dan kekonveksan. Bilangan kabur yang banyak digunakan di berbagai buku literatur adalah yang memenuhi kondisi kekonveksan dan kenormalan, sehingga bilangan kabur merupakan tipe himpunan kabur yang paling dasar.

Definisi 11. Bandwidths

Untuk himpunan kabur normal dan koveks, bandwidths atau lebar 
didefinisikan sebagai jarak antara dua titik crossover tunggal.

Lebar $(\mathrm{B})=\left|x_{1}-x_{2}\right|$, disini $\mu_{B}\left(x_{1}\right)=\mu_{B}\left(x_{2}\right)=0.5$

Definisi 12. Symetry (Simetri)

Himpunan kabur B dikatakan simetri jika MF-nya simetris terhadap suatu titik $\mathrm{x}=$ c. yaitu $\mu_{B}(c+x)=$ $\mu_{B}(c-x)$, untuk semua $x \in X$

\section{Definisi 13. Open and Closed} (Terbuka dan tertutup)

Himpunan kabur terbuka kiri jika $\lim _{x \rightarrow-\infty} \mu_{B}(x)=1$ dan $\lim _{x \rightarrow+\infty} \mu_{B}(x)=0$.

Terbuka kanan jika $\lim _{x \rightarrow-\infty} \mu_{B}(x)=$ 0 dan $\lim _{x \rightarrow+\infty} \mu_{B}(x)=1$, dan

Tertutup jika $\lim _{x \rightarrow-\infty} \mu_{B}(x)=$ $\lim _{x \rightarrow+\infty} \mu_{B}(x)=0$

\section{Definisi $14 . \quad$ Cardinality}

(Kardinalitas)

Himpunan kabur finite. kardinalitas B didefinisikan sebagai $\quad|B|=$ $\sum_{x \in X} \mu_{B}(x)$. Sedangkan untuk $|B|=\frac{|B|}{|X|}$ disebut kardinalitas relatif dari $\mathrm{B}$

\section{Fungsi Keanggotaan (Membership Function)}

Fungsi Keanggotan (MF) merupakan hal yang sangat menentukan ketepatan nilai dari suatu variabel pada semesta pembicaraan. Hal ini sangat ditetntukan oleh subyektivitas individu itu sendiri. Fungsi Keanggotaan adalah suatu kurva yang menunjukkan pemetaan titik-titik variabel data input dari semesta $\mathrm{X}$ ke nilai keanggotaannya (sering juga disebut dengan derajat keanggotaan) yang memiliki interval dari 0 sampai dengan 1. . Salah satu cara yang dapat digunakan untuk mendapatkan nilai keanggotaan adalah dengan memanfaatkan fungsi. Ada beberapa fungsi yang bisa digunakan dan cukup terkenal untuk dimensi satu antara lain adalah:

a) Representasi MF linier, misalnya

$$
\begin{aligned}
& \mu(x) \\
& =\left\{\begin{array}{cc}
0 & x \leq a \\
(x-a) /(b-a) & a \leq x \leq b \\
1 & x \geq b
\end{array}\right.
\end{aligned}
$$

b) Representasi MF kurva segitiga

$$
\begin{aligned}
& \text { segitiga }(x ; a, b, c) \\
& =\left\{\begin{array}{cc}
0 & x \leq a \text { atau } x \geq c \\
(x-a) /(b-a) & a \leq x \leq b \\
(c-x) /(c-b) & b \leq x \leq c
\end{array}\right.
\end{aligned}
$$

c) Representasi MF trapesoid

$$
\begin{aligned}
& \text { trapesoid }(x ; a, b, c, d) \\
& =\left\{\begin{array}{cc}
0 & x \leq \text { a atau } x \geq d \\
(x-a) /(b-a) & a \leq x \leq b \\
1 & b \leq x \leq c \\
(d-x) /(d-c) & c \leq x \leq d
\end{array}\right.
\end{aligned}
$$

d) Representasi MF Gauss

$$
\operatorname{gauss}(x ; c, \sigma)=e^{-\frac{1}{2}\left(\frac{x-c}{\sigma}\right)^{2}},
$$

dengan c menentukan pusat MF dan $\sigma$ menentukan lebar MF.

e) Representasi MF Bell

$$
\operatorname{bell}(x ; a, b, c)=\frac{1}{1+\left|\frac{x-c}{a}\right|^{2 b}}
$$

f) Representasi MF Sigmoid

$$
\operatorname{sig}(x ; a, c)=\frac{1}{1+\exp [-a(x-c)]^{2}}
$$

Beberapa fungsi keanggotaan (MF) yang telah diuraikan di atas dapat diimplementasikan dalam 
menyelesaikan permasalahan sehari hari. Ketepatan penggunaan MF tersebut bergantung pada konteks masalah dan subyektifitas individu dalam mencermati dan menganalisis masalahnya.

\section{Operator Dasar Dalam Himpunan Kabur}

Seperti halnya pada himpunan klasik, maka Zadeh menciptakan 3 buah operator dasar dalam himpunan kabur, yakni subset, and, or, dan not. Operator-operator ini didefinisi sebagai berikut.

\section{Definisi 15. Subset}

Ketermuatan (subset) pada himpunan kabur didefinisikan sebagai: Himpunan kabur A termuat himpunan B (himpunan bagian/subset), atau A kurang dari atau sama dengan B jika dan hanya jika $\mu_{A}(x) \leq \mu_{B}(x)$ untuk semua $x$. Secara simbolik dapat ditulis: $A \subseteq B \leftrightarrow \mu_{A}(x) \leq \mu_{B}(x)$.

\section{Definisi 16. Operator and (dan)}

Operator ini berhubungan dengan operasi irisan seperti pada himpunan klasik.

Irisan dua himpunan kabur A dan B adalah himpunan kabur $\mathrm{C}$, yakni $\mathrm{C}=$ $\mathrm{A}$ or $\mathrm{B}$, dengan MF-nya adalah $\mu_{C}(x)=\min \left(\mu_{A}(x), \mu_{B}(x)\right)=$ $\mu_{A}(x) \wedge \mu_{B}(x)$

Definisi 17. Operator or (atau) Operator ini berhubungan dengan operasi union seperti pada himpunan klasik.

Gabungan dua himpunan kabur A dan $\mathrm{B}$ adalah himpunan kabur $\mathrm{C}$, yakni $\mathrm{C}$ $=\mathrm{A}$ or $\mathrm{B}$, dengan MF-nya adalah $\mu_{C}(x)=\max \left(\mu_{A}(x), \mu_{B}(x)\right)=$ $\mu_{A}(x) \vee \mu_{B}(x)$
Definisi 18. Operator not (negasi)

Operator ini berhubungan dengan operasi negasi seperti pada himpunan klasik.

Negasi dari himpunan kabur A (negasi dari himpunan kabur A). dinyatakan dengan notasi:

not $\mathrm{A}=-A=\bar{A}$. yang didefinisikan sebagai $\mu_{\bar{A}}(x)=1-\mu_{A}(x)$

Beberapa uraian di atas memberikan dasar bagi upaya pemahaman logika dan himpunan kabur serta pemahaman sistem kabur lebih lanjut. Untuk itu, bagi pemula yang akan mempelajari mengenai teori atau sistem kabur, perlu mempelajari terlebih dahulu apa yang telah diuraikan dalam tulisan ini serta dibantu dengan membaca literatur lain yang menjadi sumber utamanya.

\section{Perlukah Logika Himpunan Kabur Masuk Kurikulum Matematika?}

Memperhatikan kenyataan dan fenomena yang terjadi dalam kehidupan sehari-hari, tentu tidak bisa dipungkiri bahwa banyak hal yang dihadapi ternyata tidak selalu bersifat dikotomi. Kehidupan manusia itu sendiri lebih banyak menghadapi persoalan yang justru bersifat kontinum. Pola pikir manusia juga lebih masuk akal bila dipengaruhi oleh situasi yang bersifat kontinum. Namun demikian, bukan berarti sifat dikotomi menjadi tidak penting, tetapi perlu ada penyempurnaan untuk melengkapi kekurangannya. Sebagai contoh, kita mengenal siang dan malam (secara dikotomi), namun bila kita cermati batas antara keduanya ternyata tidak jelas. Sementara proses terjadinya perubahan dari siang menjadi malam atau sebaliknya 
ternyata tidak secara mendadak. Tua dan muda adalah sebutan yang biasa didengar sehari-hari, baik untuk umur manusia maupun untuk istilah lain seperti untuk warna, buah-buahan, dan lain-lain. Untuk konteks ini, perubahan dari tua ke muda juga tidak terjadi secara tiba-tiba. Batas yang tegas dari contoh tersebut jelas tidak dapat ditentukan dan hal ini realitas yang terjadi secara alamiah.

Contoh lain, terkait dengan upaya mempengaruhi pemikiran manusia secara psikologis, iklan untuk mempromosikan suatu produk misalnya telah mengalami perkembangan. Semula produk iklan menggunakan logika tegas, seperti: "produk ini nomor satu", membuat persaingan antar produk yang sama menjadi "kurang sehat", dan tidak realistis karena tidak mungkin ada pemilik produk yang mempromosikan produknya menjadi "nomor dua" dan seterusnya. Bila suatu produk mengatakan "nomor satu di Indonesia", produk lain mungkin menjadi "nomor satu di Dunia". Namun, bila ada produk lain lagi yang serupa, tentu tidak mungkin lagi untuk menyatakan sebagai produk "nomor satu di Akhirat". Hal ini menjadi persoalan dan sekaligus kelemahan bila hanya berpikir secara tegas (dikotomi).

Hadirnya teori kabur (fuzzy theory) dari Zadeh, memberikan nuansa dan pekembangan baru yang sangat pesat dalam kehidupan seharihari. Munculnya teori dan sistem kabur ini telah memberikan sumbangan yang sangat besar dalam perkembangan ilmu pengetahuan dan teknologi, baik dalam bidang elektronik. kedokteran, hiburan, maupun berbagai bidang pakar. Iklan sudah berkembang promosinya menjadi produk yang "sangat kuat", "luar biasa", "tanpa tanding". "nyaman", dan lain sebagainya. Hal ini terasa lebih masuk akal dalam pikiran manusia.

Kenyataan ini memberikan alasan yang kuat bagi kita untuk memiliki pengetahuan dan kemampuan yang memadai untuk dapat melakukan analisis dan penalaran yang sesuai dengan kenyataan dan kebutuhan hidup sehari-hari. Logika sebagai kendaraan berpikir, sarana berpikir kritis. analitis, dan rasional. perlu dipelajari dan dikuasai dengan sebaik-baik. Logika klasik/tegas yang dipelajari selama ini tampaknya masih belum cukup untuk mengakomodir persoalan yang bersifat kontinum seperti contoh di atas. Untuk itu teori kabur (logika himpunan kabur) yang telah dikemukakan oleh Zadeh sudah saatnya perlu dipelajari dan dipahami sejak awal (sekolah menengah atau mahasiswa tingkat pertama). Agar proses pembelajarannya berjalan dengan baik, sangat penting memasukkan materi logika himpunan kabur ini dalam kurikulum. Hal ini bukan berati menghilangkan atau mengganti logika himpunan klasik/tegas, tetapi lebih pada upaya melengkapi pengetahuan tentang logika dan himpunan klasik/tegas. Dengan kata lain, materi logika himpunan kabur perlu diintegrasikan dalam pelajaran matematika mengenai logika dan himpunan yang telah dipelajari selama ini sebagai bagian yang tidak terpisah ataupun sebagai tambahan. 


\section{Penutup}

Logika himpunan klasik/tradisional atau biasa juga disebut dengan logika himpunan tegas. Mengingat dalam logika himpunan tegas yang dipelajari selama ini membagi nilai suatu variabel dalam dua kutub secara tegas (dikotomi), yakni YA dan TIDAK, BENAR dan SALAH, dan yang sejenisnya, maka banyak hal atau fenomena dalam kehidupan seharihari yang ternyata tidak dapat dicakup olehnya. Kelemahan dalam teori ini akhirnya dapat dilengkapi dengan hadirnya teori yang dikenal dengan nama logika himpunan kabur, atau secara umum dikenal juga dengan nama teori kabur (fuzzy theory).

Pembicaraan mengenai teori kabur atau sistem kabur, khususnya yang menjadi dasarnya adalah logika himpunan kabur, ternyata memberikan cakupan yang luas dan sesuai dengan alam pikiran manusia sehari-hari. Dengan demikian, dapat dikatakan bahwa segala fenomena yang terjadi dalam kehidupan seharihari dapat terlingkupi oleh teori kabur. Dalam teori kabur ini telah tercakup pula fenomena yang terjadi secara tegas.

Sehubungan dengan itu, penguasaan mengenai teori kabur, terutama logika himpunan kabur perlu mendapat perhatian dan dipikirkan untuk dikembangkan dan diberikan bagi siswa dan mahsiswa sejak dini. Bagi orang yang belum mengenal teori kabur ini, mungkin materi ini tampak sukar, rumit, bahkan tidak menyenangkan. Namun, bila orang mengenal dan menyadari kaitannya dengan kehidupan sehari-hari besar kemungkinan orang akan menjadi tertarik untuk mempelajarinya lebih lanjut. Mudah-mudahan tulisan singkat ini dapat memberikan pencerahan bagi kita semua, terutama yang berkecimpung dalam bidang matematika dan pendidikan matematika

\section{Daftar Pustaka}

Dubois, D., and Prade, H. (1980). Fuzzy Sets and Systems: Theory and Applications. London: Academic Press, Inc.

Jang, J.S. Roger, et.al. (1997). Neuro Fuzzy and Sofi Computing, New Jersey: Prentice Hall.

Hellmann, M. (tt). Fuzzy Logic Introduction, http:/fuzzy-logicintroduction.pdf. Diakses tanggal 29 September 2012.

Wang, L, X. (1997). A Course in Fuzzy Systems and Control. New Jersey: Prentice-Hall, Englewood Cliffs.

Zimmermann H.J. (1991) Fuzzy Sets Theory and Its Applications. Second Edition, Boston: Kluwer. 